\title{
Reflexiones desde la pedagogía feminista. Sorteando la ceguera de género en las Ciencias Económicas
}

\author{
Reflections from a Feminist Pedagogy Perspective. \\ Overcoming Gender Blindness within Economic Sciences \\ Reflexões desde a pedagogia feminista. Contornando \\ a cegueira de gênero nas Ciências Contábeis
}

\author{
María Fernanda Pagura \\ Facultad de Ciencias Económicas. \\ Universidad Nacional del Litoral, Argentina \\ E-mail:fpagura@fce.unl.edu.ar
}

\author{
Luisina Logiodice \\ Facultad de Ciencias Económicas. \\ Universidad Nacional del Litoral, Argentina \\ E-mail: luisinalogiodice@gmail.com
}

Fecha de Recepción: 04/12/2020 Fecha de Aceptación: 17/06/2021

Palabras clave - enseñanza de la metodología de la investigación

- perspectiva de género

- ciencias económicas

- educación superior

\section{Resumen}

Tal como lo demuestran múltiples investigaciones, los discursos y prácticas educativas universitarias producen saberes y mandatos atravesados por el androcentrismo y sexismo, de los que no quedan exentas la economía y la administración. Complejizar el abordaje disciplinar de las problemáticas sociales desde la perspectiva de género invita a leer el mundo en clave de relaciones de poder que se expresan en los nichos de injusticia social, económica, política y sexual. Para ello, es necesario no solo analizar aquello que se dice acerca del mundo en términos discursivos, sino también atender a los procedimientos que juegan en la producción científica. En este sentido, es posible señalar que la crítica epistemológica y metodológica al enfoque dominante en dichas disciplinas constituye un paso indispensable para el desarrollo de la perspectiva feminista en las facultades de Ciencias Económicas.

Este trabajo recupera, en clave de género, el recorrido de los dos últimos años de la cátedra Metodología de la Investigación que se dicta en el 3er. año de las carreras Lic. en Economía y Lic. en Administración 
de la Facultad de Ciencias Económicas de la UNL (Santa Fe, Argentina). Interesa mostrar, primeramente, el posicionamiento epistemológico feminista que se plasma en la propuesta didáctico pedagógica de la materia y que dialoga con los decires del estudiantado. En segundo lugar, explicitar algunas formas de materialización del sexismo en el curriculum prescripto, oculto y nulo en la formación profesional.

\begin{abstract}
As it has been demonstrated by numerous research works, discourses and educational practices in university produce knowledge and dictates of conscience which are penetrated by androcentrism and sexism: Economics and Administration are not the exception. Making the disciplinary approach of social issues from a gender perspective more complex invites us to understand the world from the point of view of power relationships which are expressed in social, economic, political and sexual injustice niches. In order to achieve this, it is necessary to analyze not only what is said about the world in terms of discourse but also the procedures which play a role in scientific production. Therefore, an epistemic and methodological criticism of the predominant focus within such disciplines constitutes an essential step towards the development of a feminist perspective in the Schools of Economic Sciences.

This paper revisits, from a gender point of view, the experiences of the last two years of the subject 'Research Methodology' from the third year of the bachelor's degree in Economics and in Administration of Universidad Nacional del Litoral (Santa Fe, Argentina). Firstly, we are interested in showing the feminist epistemic positioning which is expressed in the didactic and pedagogical proposal of the subject and which also considers students' impressions. Secondly, we would like to explicitly state some forms of materialization of sexism within the prescribed, hidden and null curriculum in professional education
\end{abstract}

Keywords

- economic sciences

- higher education

- gender perspective

- research methodology teaching

\title{
Resumo
}

Assim como 0 demostram múltiplas pesquisas, os discursos e práticas educativas universitárias produzem conhecimentos e mandados atravessados pelo androcentrismo e sexismo, não ficando isentas a economia e a administração. Diversificar a abordagem disciplinar das problemáticas sociais desde a perspectiva de gênero convida a ler o mundo desde as relações de poder, que se expressam nos nichos da injustiça social, econômica, política e sexual. Para tanto, é necessário não só analisar aquilo que se diz a respeito do mundo em termos discursivos, mas também dar atenção aos procedimentos que atuam na produção científica. Neste sentido, é possível marcar que a crítica epistemológica e metodológica ao enfoque dominante nessas disciplinas constitui um passo indispensável 
Palavras-chave

- ciências contábeis

- educação superior

- ensino da metodologia de pesquisa

- perspectiva de gênero para o desenvolvimento da perspectiva feminista nas faculdades de Ciências Contábeis.

Este trabalho recupera, desde um olhar de gênero, o percurso dos dois últimos anos da cátedra Metodologia da Pesquisa que é lecionada no terceiro ano dos cursos Bacharelado em Economia e Bacharelado em Administração da Faculdade das Ciências Contábeis da UNL (Santa Fe, Argentina). É de interesse mostrar, em primeiro lugar, o posicionamento epistemológico feminista, que se fixa na proposta didático-pedagógica da disciplina, e que dialoga com os dizeres dos estudantes. No segundo lugar, explicitar algumas formas de materialização do sexismo no currículo prescrito, oculto e nulo na formação profissional. 